\title{
On the $\mathrm{CO}_{2}$ sorption and swelling of elastomers
}

\section{by supercritical $\mathrm{CO}_{2}$ as studied by}

\section{in situ high pressure FTIR microscopy}

\author{
Julie DUBOIS ${ }^{1}$, Etienne GRAU ${ }^{1}$, Thierry TASSAING ${ }^{*}{ }^{2}$, Michel DUMON*1 \\ ${ }^{1}$ LCPO, UMR 5629 CNRS, Univ. Bordeaux, IPB, 33600 Pessac, France \\ 2 ISM, UMR 5255,CNRS Univ. Bordeaux, 33400 Talence, France
}

Corresponding authors: Thierry TASSAING, Michel DUMON

Highlights

$>$ Simultaneous $\mathrm{CO}_{2}$ sorption and swelling of elastomers using high pressure FTIR microscopy.

$>$ Investigation of seven elastomers for $\mathrm{T}=50$ to $110^{\circ} \mathrm{C}$ from $\mathrm{P}=5$ to $15 \mathrm{MPa}$

$>$ All the elastomers displays a significant level of $\mathrm{CO}_{2}$ sorption about $20 \%$ at $\mathrm{P}=15 \mathrm{MPa}$.

$>$ The resulting swelling is linearly correlated to the $\mathrm{CO}_{2}$ sorption.

$>$ Weak dependence of swelling and $\mathrm{CO}_{2}$ sorption upon temperature variation. 


\begin{abstract}
An FTIR (Fourier Transform InfraRed) microscope combined to a high pressure cell has been used to determine the $\mathrm{CO}_{2}$ solubility in several common elastomers: EPDM, CR, IR, SBR, EVM and NBR. Both the $\mathrm{CO}_{2}$ sorption and the resulting swelling of the elastomers have been determined as function of pressure $(\mathrm{P}=5-15 \mathrm{MPa})$ at constant temperature $\left(\mathrm{T}=50^{\circ} \mathrm{C}\right)$. A significant quantity of $\mathrm{CO}_{2}$ is sorbed in all studied elastomers, between 15 and $20 \%$ at $\mathrm{T}=50^{\circ} \mathrm{C}$ and $\mathrm{P}=15 \mathrm{MPa}$ for most elastomers and up to $30 \%$ for EVM in the same conditions. The resulting percentage of swelling of the elastomers is significant and nearly equal to the $\mathrm{CO}_{2}$ mass uptake for most of the studied elastomers. The effect of temperature has been studied for $\mathrm{EPDM}$, between $\mathrm{T}=50^{\circ} \mathrm{C}$ and $\mathrm{T}=110^{\circ} \mathrm{C}(\mathrm{P}=5-15 \mathrm{MPa})$ and demonstrate that the swelling and $\mathrm{CO}_{2}$ sorption of EPDM displays only a weak variation in this temperature range. Few data are available in the literature for elastomers.
\end{abstract}

\title{
1 - INTRODUCTION
}

Supercritical (sc) fluids have long been known as good solvents, good reaction media, extraction, separation or degradation media, molecular carriers, mass and heat transport media [1-3].

Among sc fluids, the $\mathrm{CO}_{2}$ molecule switches easily between the liquid, gas and supercritical (sc) states, the critical point being rather low at $31^{\circ} \mathrm{C}, 74$ bars. Although $\mathrm{CO}_{2}$ is the primary greenhouse gas emitted through human activities, it is an industrially used molecule in its sc state as a reaction solvent [4], as a blowing agent [5], as a transport medium for the introduction of active ingredients or for the extraction of toxic ingredients [6,7] in all kinds of solids.

At a given pressure and temperature within the sc state, when such a low molar mass molecule flows into a solid polymer, several types of physical phenomena occur : sorption, absorption, diffusion, solubility and swelling [8-11]. These phenomena are governed by the polymer/ $\mathrm{CO}_{2}$ interactions and the particular properties of the sc state. Indeed the supercritical state enhances the $\mathrm{CO}_{2} /$ polymer interactions because sc $\mathrm{CO}_{2}$ combines simultaneously a very good solvent capability and a very good 
diffusion capacity. But depending on the polymer, the knowledge of $\mathrm{CO} 2 /$ polymer interactions is more or less accessible or sometimes poorly affordable. Glassy amorphous polymers are the most studied polymers [12,13], semi crystalline polymers are commonly studied [13-16] whereas reinforced, filled, or biphasic materials are becoming more and more studied $[14,17,18]$

However studies (e.g refs [16,19-22]) are rather scarce when dealing with the behavior of elastomers (neat or filled) in $\mathrm{CO}_{2}$. The reasons are twofold: i) rubbery polymers are expected to be highly deformable in $\mathrm{CO}_{2}$ (involving a high swelling), ii) the sorption/desorption stages are fast. Swelling may not be isostatic and elastomers may even creep. All of this makes data recovery and studies difficult.

In this study we rely on a well-established technique (high pressure near infra-red microcopy -NIR $\mu$ scopy) and we develop this technique to extract several data dealing with diffusion, swelling and solubility of $\mathrm{CO}_{2} /$ unfilled elastomer systems (various Pressures and Temperatures). It is an in-situ method, providing a one-step measurement, applicable to any sample thickness. An expected drawback is that diffusion is not unidirectional.

We chose a panel of engineering elastomers (EPDM, CR, EVM, IR) from raw uncrosslinked rubbers to thermoplastic elastomers, with different chemical interacting groups towards $\mathrm{CO}_{2}$ (different polarities).

\section{2 - EXPERIMENTAL DETAILS}

\subsection{Materials}

Carbon dioxide N45 (purity 99,95\%) was supplied by Air Liquide. EPDM (s), CR, EVM, IR, SBR, NBR/PVC were purchased from international companies. Structures and properties of the polymers used in this study are displayed in Table 1

\begin{tabular}{|l|c|c|c|c|c|c|}
\hline Polymer & Structure & Density & Crystallinity & $\mathbf{T}_{\mathbf{g}}$ & $\mathbf{M}_{\mathbf{n}}$ & Supp. Info \\
$\left({ }^{\circ} \mathrm{C} \cdot \mathrm{cm}^{-3}\right)$ & & $\left(\mathrm{g} \cdot \mathrm{mol}^{-1}\right)$ & \\
\hline EPDM 1 & & 0.86 & amorphous & -44 & 165000 & high molecular weight \\
\hline
\end{tabular}




\begin{tabular}{|c|c|c|c|c|c|c|}
\hline EPDM 2 & & 0.86 & amorphous & -51 & 112000 & low molecular weight \\
\hline IR & & n.d. & amorphous & -70 & 271000 & /// \\
\hline SBR & & n.d & amorphous & -55 & 110000 & \\
\hline CR & & 1.23 & Semi-cristalline & -40 & 540000 & /// \\
\hline EVM & & 1.07 & amoprhous & -11 & 196000 & Vinyl acetate content: $70 \%$ \\
\hline $\begin{array}{c}\text { NBR/PVC } \\
\text { Physical } \\
\text { blend, } \\
\text { NBR matrix } \\
\end{array}$ & & $\begin{array}{c}\text { Poorly } \\
\text { characterized } \\
\text { (P.C.) }\end{array}$ & P.C. & P.C & P.C & P.C \\
\hline
\end{tabular}

Table 1: Physical and chemical properties of the studied elastomers

\subsection{Infrared micro-spectroscopy}

\section{2.a. Experimental set-up}

The set-up consists in a FTIR microscope working in transflection mode coupled with a high pressure cell. The infrared absorption measurements were performed using an Infrared microscope Perkin Elmer Spotligh 200 that allows investigating the spectral range (800-6500 $\mathrm{cm}^{-1}$ ) with a spatial resolution of $100 \mu \mathrm{m}^{2}$. Single beam spectra recorded with a $4 \mathrm{~cm}^{-1}$ resolution were obtained after the Fourier transformation of 50 accumulated interferograms. The home-made stainless steel vessel was equipped with a sapphire window and a mirror in between the polymer sample was maintained as shown in Figure 1. This cell was designed in order to withstand a pressure of about $20 \mathrm{MPa}$ for temperature ranging between 20 and $150^{\circ} \mathrm{C}$. A $100 \mu \mathrm{m}$ Teflon foil was placed between the window and the cell body to compensate for any imperfections between the two surfaces. Two thermocouples were used, the first one located close to a cartridge heater for the temperature regulation and the second one close to the sample area to measure the temperature of the sample with an accuracy of about $1^{\circ} \mathrm{C}$. The cell was connected via a stainless steel capillary to a hydraulic pressurizing system, which permits the pressure to be raised up to $50 \mathrm{MPa}$ with a standard uncertainty $\mathrm{u}(\mathrm{P})=0.1 \mathrm{MPa}$. The stabilization of the operating conditions was controlled by recording several consecutive spectra. The 
experiments were performed at fixed temperature of $50^{\circ} \mathrm{C}$ and in a pressure range from 5 to 15 MPa.

\section{2.b. Experimental Procedure}

From the bulk polymeric sample, a piece was cut with a thickness of about $0.5 \mathrm{~mm}$, a width of about $1.5 \mathrm{~mm}$ and a length of about $4 \mathrm{~mm}$. The sample was placed between the window and the mirror, the position of which could be adjusted in order to hold a good contact between the window and the mirror, see Figure 1. The mirror used was made of stainless steel polished to obtain a good reflection of the IR beam. Under this geometry, $\mathrm{CO}_{2}$ could diffuse into the polymer from the four lateral sides of the polymer sample. Then, the cell was heated up to the required temperature. The spectra were recorded for the polymer sample alone then $\mathrm{CO}_{2}$ was added up to the desired pressure. During the stabilization of the operating conditions, consecutive spectra were recorded every $5 \mathrm{~min}$. For each series of measurements, absorption IR spectra have been plotted as function of time to check that the equilibrium has been reached typically after a period of time between 30 and 150 min depending upon the temperature and pressure conditions and the nature of the polymer. Figure 2 is an example of the evolution of absorbance at $50^{\circ} \mathrm{C}$ et $5 \mathrm{MPa}$ for every elastomers.
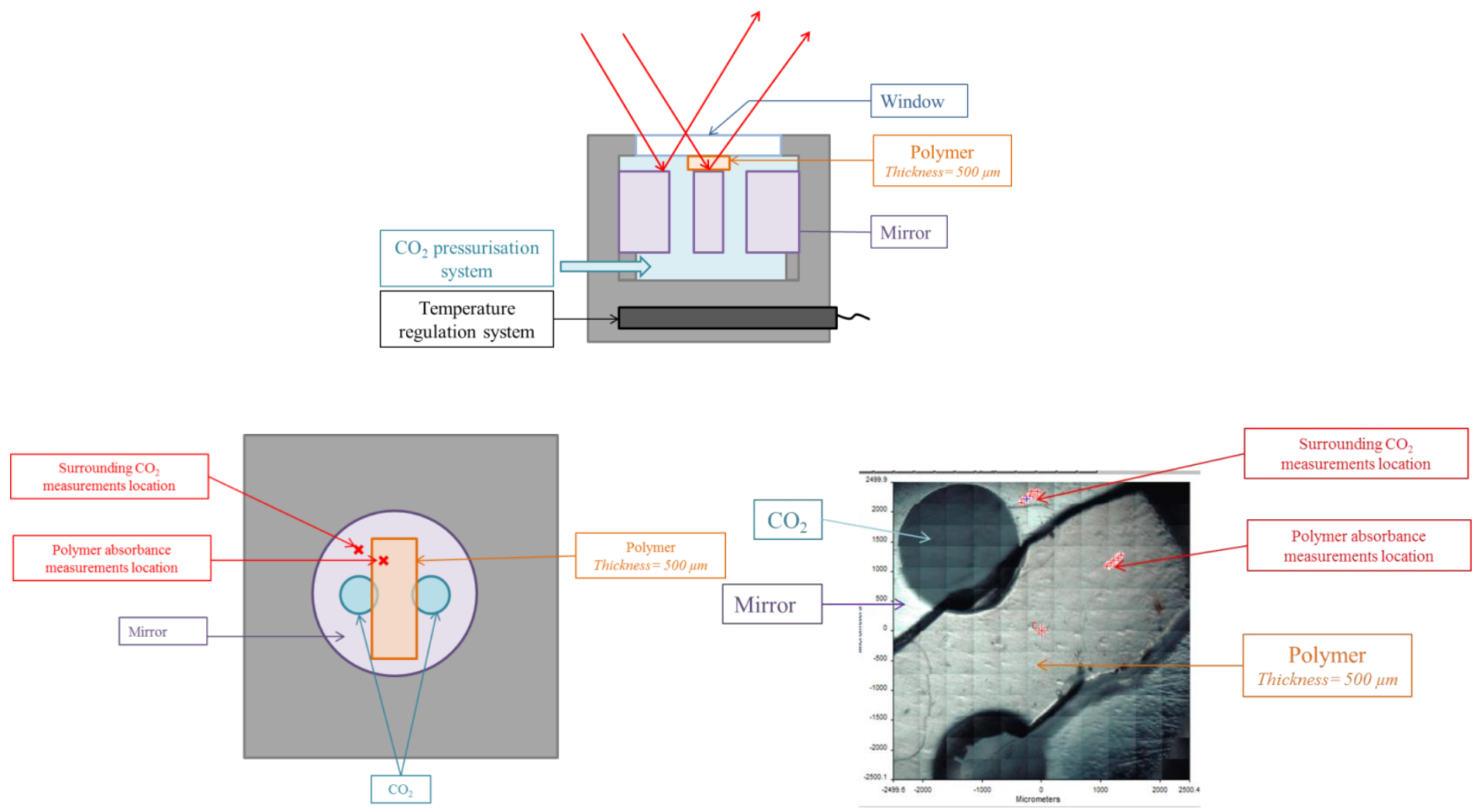

Figure 1 Experimental setup 


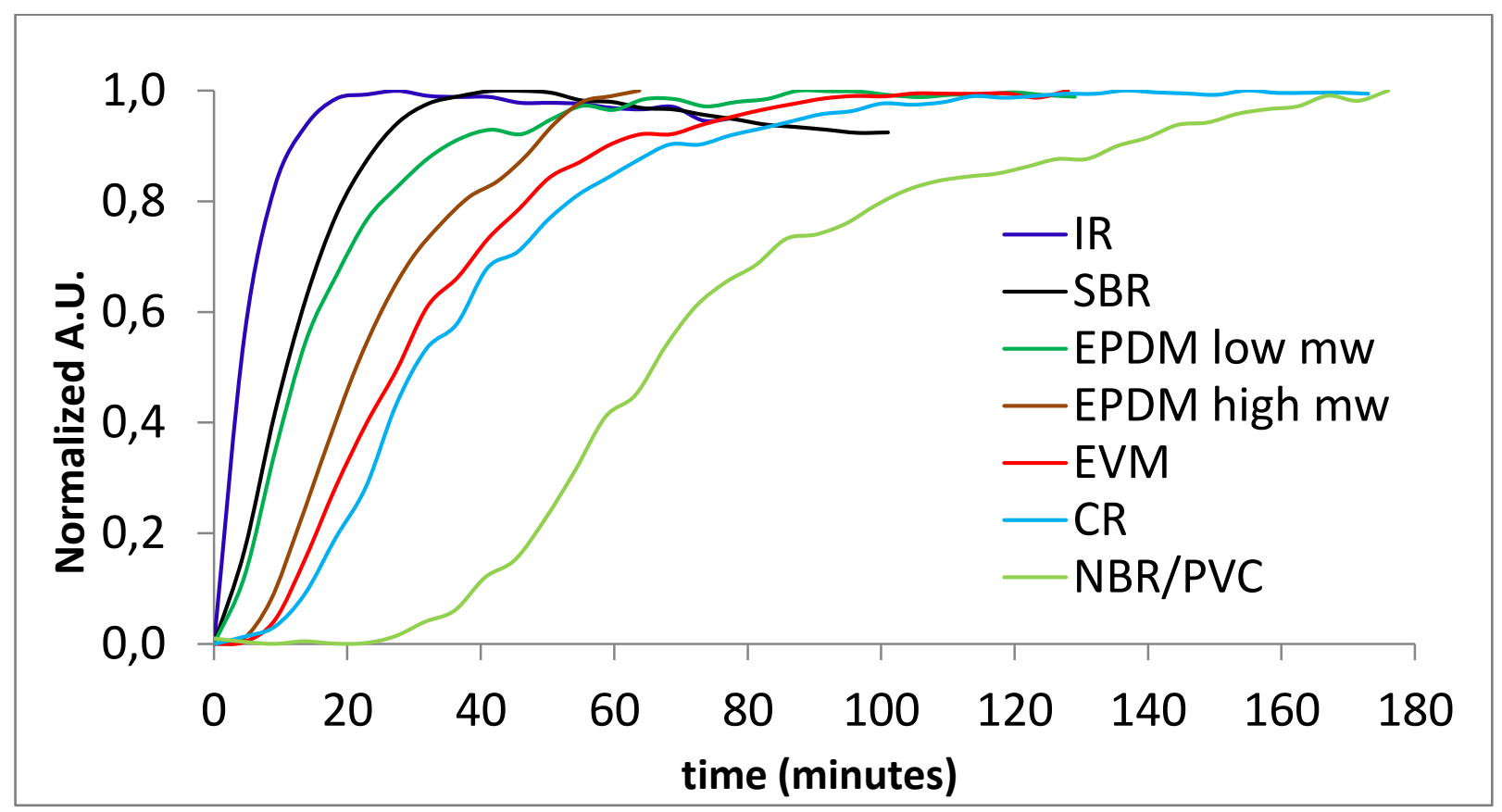

Figure 2 Evolution of the absorbance of the peak centered at $4950 \mathrm{~cm}-1$ (this band is assigned to $\mathrm{CO}_{2}$, it is expressed in normalized unit) at $\mathrm{T}=50^{\circ} \mathrm{C}$ and $\mathrm{P}=5 \mathrm{MPa}$

\section{3 - INFRARED SPECTRA AND DATA PROCESSING}

\subsection{Infrared absorption spectra}

\section{Polymer}

The infrared spectra of the different polymers swelled by $\mathrm{CO}_{2}$ were recorded at $50^{\circ} \mathrm{C}$ for various pressures ranging between 0.1 and $15 \mathrm{MPa}$. Figure 3 displays the typical changes of the EPDM 1 or 2 infrared spectra that can be observed upon an increase of $\mathrm{CO}_{2}$ pressure. A number of significant peaks associated with fundamental and combination modes of $\mathrm{CO}_{2}$ and polymer can be observed.

Regarding the polymer, the peaks detected in the range $2900-3100 \mathrm{~cm}^{-1}$ are associated to fundamental C-H stretch vibrations, that observed in the range $4000-4500 \mathrm{~cm}^{-1}$ are associated to $\mathrm{C}-\mathrm{H}$ combination modes and finally the contribution detected in the range $5500-6000 \mathrm{~cm}^{-1}$ is associated to $\mathrm{C}-\mathrm{H}$ overtones. We emphasize that all polymers investigated in this study displays the same characteristic 
infrared bands. The peaks observed at about $3000 \mathrm{~cm}^{-1}$ are saturated in our experimental conditions. Besides, the group of peaks observed in the range 4000-4200 $\mathrm{cm}^{-1}$ strongly overlapped making difficult their analysis to get accurate quantitative information. Consequently, we have used the peaks associated to $\mathrm{C}-\mathrm{H}$ overtones centered at about $5800 \mathrm{~cm}^{-1}$ to determine the swelling of EPDM subjected to $\mathrm{ScCO}_{2}$.

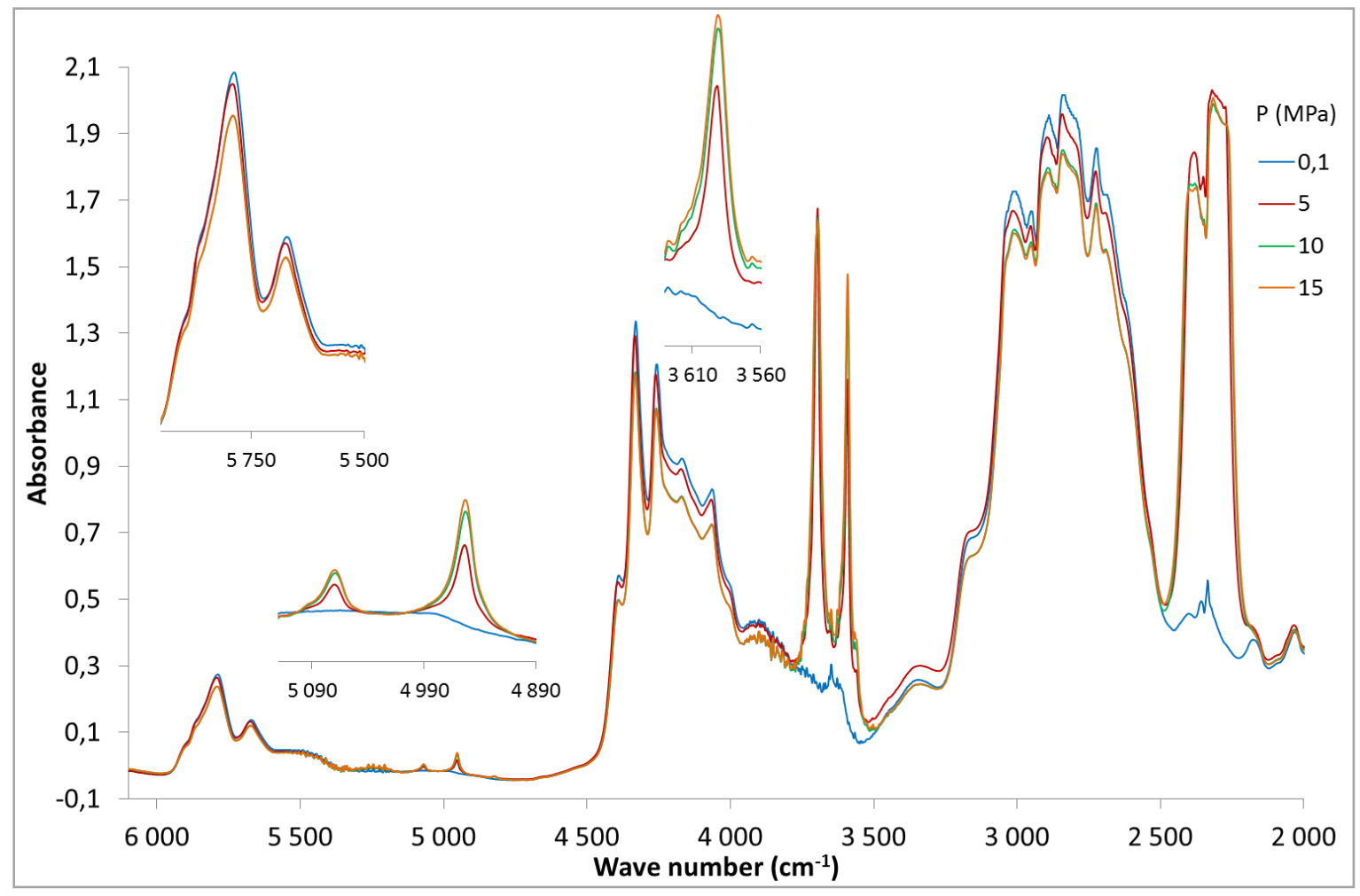

Figure 3: Infrared spectra of EPDM 1 at $50^{\circ} \mathrm{C}$ under a $\mathrm{CO}_{2}$ pressure of $0.1 \mathrm{MPa}, 5 \mathrm{MPa}, 10 \mathrm{MPa}$ and $15 \mathrm{MPa}$ 
Concerning $\mathrm{CO}_{2}$, five peaks can be detected. Peak at 2300 is assigned to the antisymetric stretch $v_{3}$, 3590 is assigned to combination modes $2 v_{2}+v_{3}, 3695$ assigned to combination mode $v_{1}+v_{3}, 4950 \mathrm{~cm}^{-}$ ${ }^{1}$ is assigned to combination mode $v_{1}+2 v_{2}+v_{3}$ and 5030 is assigned to $2 v_{1}+v_{3}$ of $\mathrm{CO}_{2}$ molecule.

Most intense peak, centered at $2300 \mathrm{~cm}^{-1}$, is saturated in our experimental conditions and cannot be used for our purpose. The peak centered at $3590 \mathrm{~cm}-1$ could be used for quantitative measurements but only for pressures below $5 \mathrm{MPa}$. Above this pressure, peak is saturated and linearity hypothesis between the IR absorbance and the concentration is not valid anymore. To sum up, the bands at 3590 $\mathrm{cm}^{-1}, 3695 \mathrm{~cm}^{-1}, 4950 \mathrm{~cm}^{-1}$ and $5066 \mathrm{~cm}^{-1}$ were used to estimate the evolution of the weight percentage of $\mathrm{CO}_{2}$ sorbed into the polymers, depending on the saturation or not of the peak at 3590 $\mathrm{cm}^{-1}$. Besides, we emphasize that these peaks can be assigned unambiguously to $\mathrm{CO}_{2}$ sorbed into the polymer and not to surrounding $\mathrm{CO}_{2}$, since the peaks of surrounding $\mathrm{CO}_{2}$ are detected at higher wavenumbers (3610, 3710 and $4970 \mathrm{~cm}-1$ and $5100 \mathrm{~cm}-1$ for the combination modes) as depicted in Figure 4. This kind of shift was also reported in the literature [23].

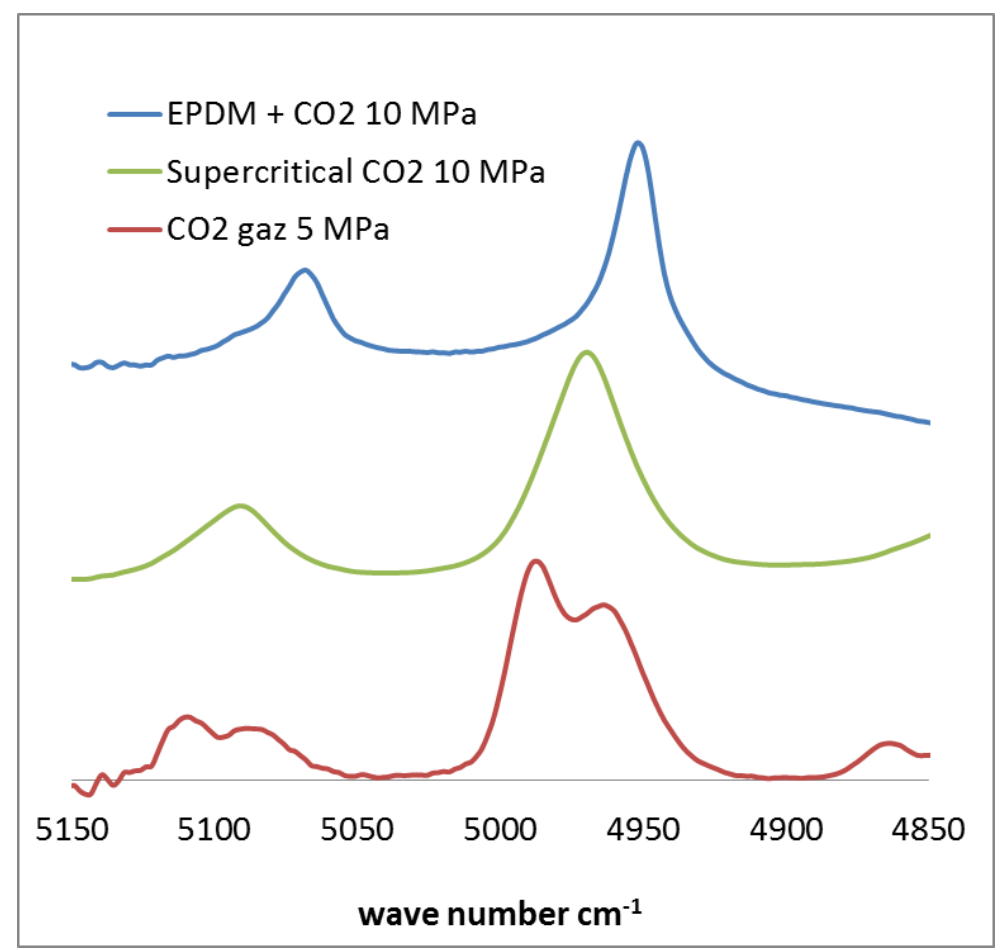

Figure 4: Infrared spectra of $\mathrm{CO}_{2}$ at $\mathrm{T}=50^{\circ} \mathrm{C}$ and $\mathrm{P}=5 \mathrm{MPa}$ (neat gaseous $\left.\mathrm{CO}_{2}\right), \mathrm{P}=10 \mathrm{MPa}$ (neat $\left.\mathrm{scCO}_{2}\right)$ and $\mathrm{P}=10 \mathrm{MPa}\left(\mathrm{CO}_{2}\right.$ in EPDM) 


\subsection{Determination of polymer swelling and $\mathrm{CO}_{2}$ sorption: data processing}

\section{2.a. Polymer swelling}

Guadagno et al [24] has proposed a calculation of the polymer swelling via the absorbance of a specific band of the polymer before and during exposure to $\mathrm{CO}_{2}$, and based on the Beer-Lambert law.

$$
A_{0}=\text { e.l. } C_{0}(1) \quad A=\text { e.l.C }
$$

where $A_{0}$ and $A$ are the absorbances of the polymer bands before and after exposure to $\mathrm{CO}_{2}$, respectively; $l$ is the pathlengths $(\mathrm{cm}) ; C_{0}$ and $C$ are the concentration of polymer before and after exposure to $\mathrm{CO}_{2}$, respectively $\left(\mathrm{mol} . \mathrm{L}^{-1}\right) ; \varepsilon$ is the molar extinction coefficient of the polymer band $\left(\mathrm{mol} . \mathrm{L}^{-1} \cdot \mathrm{cm}^{-1}\right)$. The molar extinction coefficient $\varepsilon$ is considered to be independent of the $\mathrm{CO}_{2}$ density. In addition, the pathlength was fixed because the elastomeric sample was held between the window and the mirror and swelling occurred in two dimensions only.

If $V$ and $V+\Delta V$ are the volume of the polymer before and after exposure to gas respectively, one can write:

$\frac{c_{0}}{c}=\frac{V+\Delta V}{V}=1+\frac{\Delta V}{V}=1+S$

Finally, after combination of these three equations (1), (2) and (3), the swelling $\mathrm{S}$ is given by:

$$
S=\frac{A_{0}}{A}-1
$$

For studied elastomers, peak around $5800 \mathrm{~cm}^{-1}$ have been used to calculate polymer swelling. As shown on Figure 3, the intensity of the peak decreases with the $\mathrm{CO}_{2}$ sorption. 


\section{2.b. $\mathrm{CO}_{2}$ sorption}

In order to determine the concentration of $\mathrm{CO}_{2}\left(C_{\mathrm{CO}_{2}}\right)$ sorbed into the polymer, the BeerLambert law has been applied to the $\mathrm{CO}_{2}$ peaks. In order to directly use the concentration of $\mathrm{CO}_{2}$ for further calculation, it has been calculated in $\mathrm{g} \cdot \mathrm{cm}^{-3}$ using the equation 6 :

$$
C_{\mathrm{CO}_{2}}=\frac{A}{\varepsilon . l} \times M_{\mathrm{CO}_{2}} \times 10^{-3}
$$

where $A$ is the absorbance of the $\mathrm{CO}_{2}$ band; $\varepsilon$ is the molar extinction coefficient; $l$ is the pathlength; $M_{\mathrm{CO} 2}$ is the molar mass of $\mathrm{CO}_{2}$ and equal to $44 \mathrm{~g} \cdot \mathrm{mol}^{-1}$.

The characteristic peaks of $\mathrm{CO}_{2}$ centered at 3715 and $4950 \mathrm{~cm}^{-1}$ were used for the absorbance measurements. For $4950 \mathrm{~cm}-1$ peak, both the height and the integrated area were used. Concerning the other peaks $\left(3590,3695\right.$ and $\left.5066 \mathrm{~cm}^{-1}\right)$ the peak heights were used instead of integrated area because the baseline choice produces larger errors.

The molar extinction coefficient considering the peaks height were estimated to be about $\varepsilon_{3695 \mathrm{~cm}-1}=$ $8.28 \mathrm{~L} \cdot \mathrm{mol}^{-1} \cdot \mathrm{cm}^{-1} ; \varepsilon_{3590 \mathrm{~cm}-1}=4.6 \mathrm{~L} \cdot \mathrm{mol}^{-1} \cdot \mathrm{cm}^{-1}$ and $\varepsilon_{4950 \mathrm{~cm}-1}=0.25 \mathrm{~L} \cdot \mathrm{mol}^{-1} \cdot \mathrm{cm}^{-1}$ and $\varepsilon_{5066 \mathrm{~cm}-1}=0.086$ L.mol ${ }^{-1} \cdot \mathrm{cm}^{-1}$. Concerning the $4950 \mathrm{~cm}^{-1}$ peak integrated area, the molar extinction coefficient is estimated to be about $\varepsilon_{4950 \mathrm{~cm}-1}=7$ L.mol ${ }^{-1} \cdot \mathrm{cm}^{-2}[23][11][25]$

Regarding the determination of the pathlength, as the elastomeric polymers are quite soft, it cannot be measured before introduction in the IR cell. Indeed, the elastomeric samples are significantly compressed when held between the mirror and the window. That is why the pathlength $l$ has been evaluated by recording a spectrum of the surrounding $\mathrm{CO}_{2}$ right next to the polymeric sample for the 3 different pressures as shown in Figure 5. Thanks to the Beer-Lambert law, the pathlength can be determined using the following equation:

$l=\frac{A_{\mathrm{CO} 2}}{\mathcal{E}^{*} C_{\mathrm{CO} 2}}$

Where $A_{\mathrm{CO} 2}$ is the absorbance of the characteristic peak of $\mathrm{CO}_{2}$ and $C_{\mathrm{CO} 2}$ the concentration of $\mathrm{CO}_{2}$. for the given pressure and temperature that is known from the literature [26]. 
In order to determinate 1, the integrated area of the peak at $4950 \mathrm{~cm}^{-1}$ was used. For each experiment, absorbance as function of $\mathrm{CO}_{2}$ concentration has been plot and $l$ has been determined thanks to the chart slope which is equal to $\varepsilon . l$ (Fig 6).

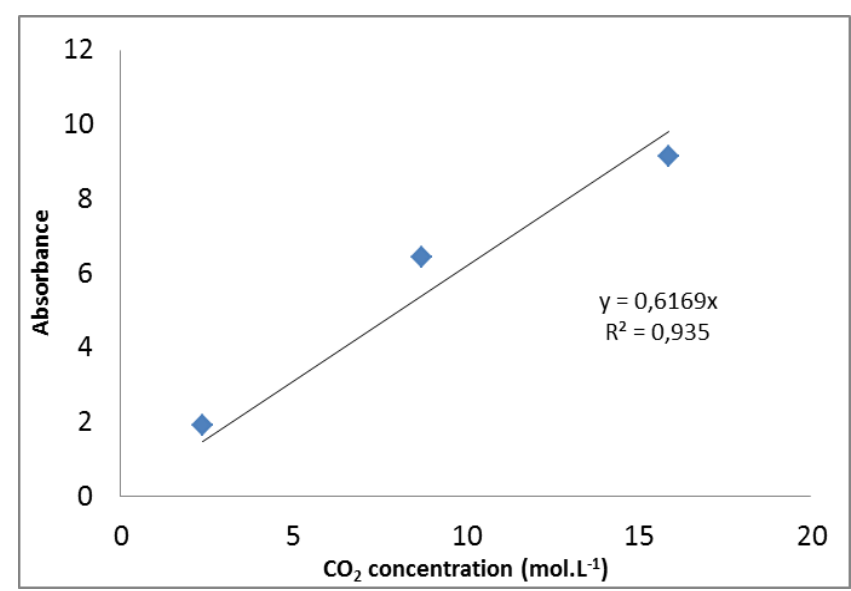

Figure 5 : $\mathrm{CO}_{2}$ concentration (neat $\mathrm{CO}_{2}$ ) as function of integrated area

$\mathrm{OR}$ albsorbance of $4950 \mathrm{~cm}^{-1}$ peaks for path length calculation, at $\mathrm{T}=\mathbf{5 0}{ }^{\circ} \mathrm{C}$

Finally, for a direct comparison with the literature data, the weight percentage of $\mathrm{CO}_{2}\left(\%\right.$ massCO $\left.\mathrm{O}_{2}\right)$ sorbed into the polymer was calculated using the following equation:

$$
\text { \%mass } \mathrm{CO}_{2}=\frac{\mathrm{C}_{\mathrm{CO}_{2}}}{C_{\mathrm{CO}_{2}}+\frac{\rho_{\text {pol }}}{1+S}}
$$

where $\rho_{p o l}$ is the initial polymer density (g.cm-3) and S the swelling.

For each elastomer and for every pressure, four values of absorbance at least have been taken into account: height of peak at $5066 \mathrm{~cm}^{-1}, 4950 \mathrm{~cm}^{-1}$ and $3590 \mathrm{~cm}^{-1}$ and integrated area of peak at $4950 \mathrm{~cm}^{-}$ 1. At $5 \mathrm{MPa}$, a fifth value could be added: the height of the peak à $3693 \mathrm{~cm}-1$. Figure 6 give the example of determination of $\%$ mass $\mathrm{CO}_{2}$ in EPDM 1 or 2 . For each condition, the four or five values calculated thanks to the different peaks are in a good agreement hence validating our methodology. In following paragraphs, the average value of $\%$ mass uptake is given. 


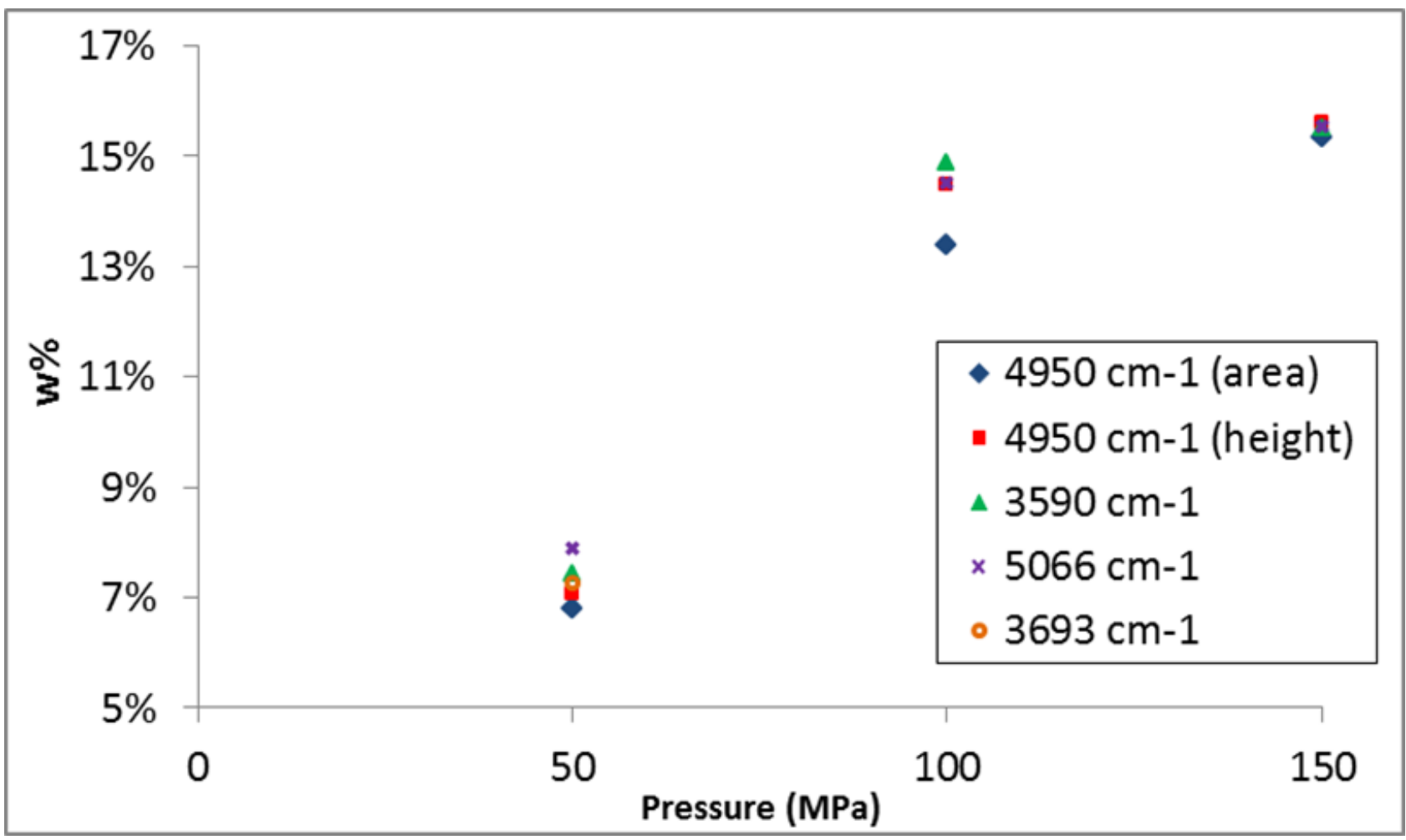

Figure $6: \%$ mass $\mathrm{CO}_{2}$ in EPDM data points at 50, 100 and 150 bars and 50 ${ }^{\circ}$, calculated thanks to every $\mathrm{CO}_{2}$ specific peaks.

Taking into account all the source of errors associated with our methodology (baseline correction, constant molar extinction coefficient, spectrometer stability), we have evaluated a relative standard uncertainty $\operatorname{ur}\left(\mathrm{C}_{\mathrm{CO} 2}\right)=0.1$ on our concentration values. We emphasize that the reliability of such methodology has already been demonstrated in previous investigations [23] [25]. 


\section{4- Results and discussion}

\section{2 $\mathrm{CO}_{2}$ sorption and swelling}

$\mathrm{CO}_{2}$ sorption and swelling measurements have been performed at $50^{\circ} \mathrm{C}$ and at $5 \mathrm{MPa}, 10 \mathrm{MPa}$ and 15 $\mathrm{MPa}$ for every studied elastomer. Maximum $\mathrm{CO}_{2}$ mass uptake $\left(\%\right.$ mass $\left.\mathrm{CO}_{2}\right)$ at equilibrium has been calculated thank to Equation 7. On Figure 7\% mass $\mathrm{CO}_{2}$ as function of pressure has been represented for each polymer.

$\mathrm{CO}_{2}$ sorption is quite similar for all studied elastomer except in the case of EVM. At $15 \mathrm{MPa}$ and $50^{\circ} \mathrm{C}$, a maximum $\mathrm{CO}_{2}$ mass uptake is between $15 \%$ and $20 \%$ for most of the studied elastomer and about $45 \%$ for EVM.

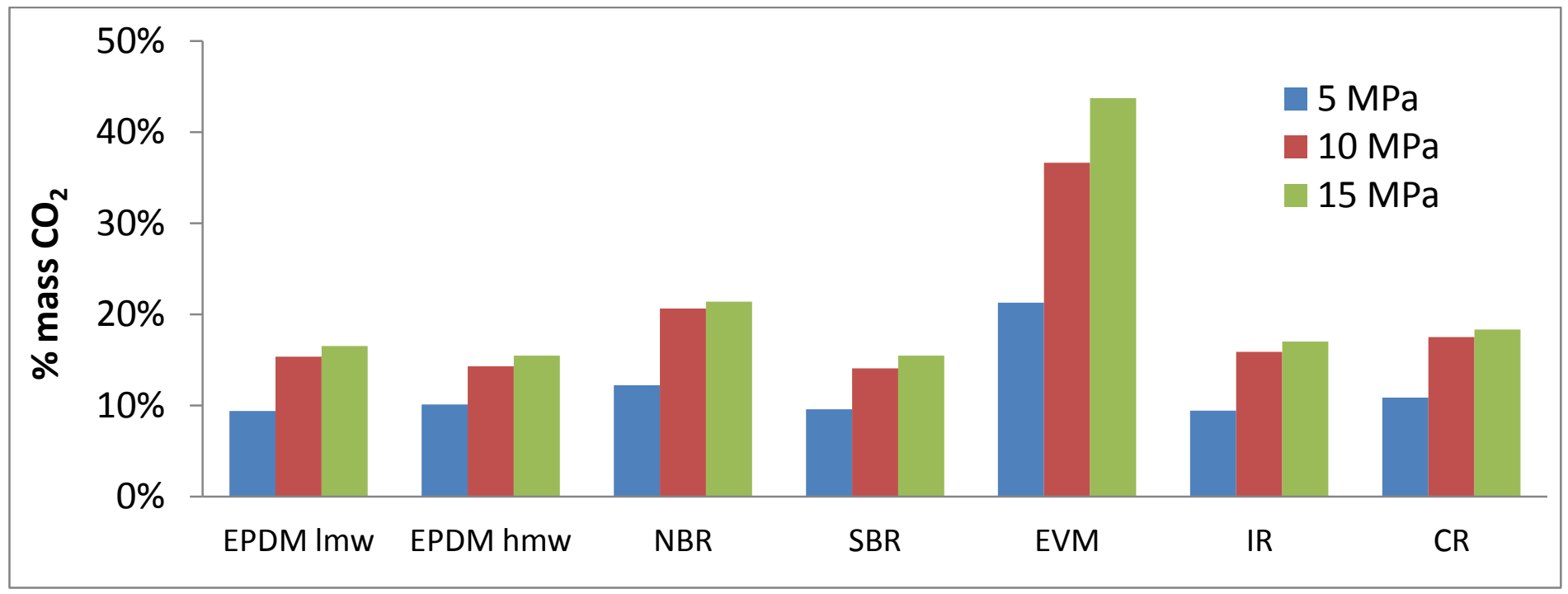

Figure $7: \mathrm{CO}_{2}$ mass uptake (\% mass $\left.\mathrm{CO}_{2}\right)$ as function of pressure, in every studied elastomer, at $\mathrm{T}=50^{\circ} \mathrm{C}, \mathrm{P}=5 \mathrm{MPa}, \mathrm{P}=10 \mathrm{MPa}$ and $P=15 \mathrm{MPa}$

Although there are very few data concerning measurements of $\mathrm{CO}_{2}$ absorption and swelling in generalpurpose elastomers. Mickaeli et al [27] measured $\mathrm{CO}_{2}$ absorption in an EPDM through in-situ gravimetric method (magnetic suspension balance). Their EPDM sample (Buna EP G 3550) has similar physico-chemical properties (molar mass, ENB content) as the two EPDM samples investigated here. At $65^{\circ} \mathrm{C}$ and 100 bars, their EPDM sample exhibits a mass uptake of about $20 \%$ which is in good qualitative agreement with our result. 
The higher $\mathrm{CO}_{2}$ sorption of EVM compare to the other polymers reported in this study is in agreement with the work of Jacobs et al [28]. Indeed, they performed some measurements on EVA with a vinyl acetate content of $40 \%$ through pressure decay method. For a $\mathrm{CO}_{2}$ pressure of $15 \mathrm{MPa}$ at $50^{\circ} \mathrm{C}$, a $\mathrm{CO}_{2}$ mass uptake of about $36 \%$ is reported versus a mass uptake of about $45 \%$ for our EVM sample (vinyl acetate content of 70\%). Therefore, the higher the vinyl acetate content in an EVM sample, the higher the $\mathrm{CO}_{2}$ sorption as previously discussed in the study of Jacobs et al. This behaviour can be explained by the well-known good affinity between $\mathrm{CO}_{2}$ and acetate function that is exploited for the design of $\mathrm{CO}_{2}$ philic polymers [29].

Concerning the relation between the pressure increase and the amount of $\mathrm{CO}_{2}$ absorbed in elastomer matrix: as expected, the $\mathrm{CO}_{2}$ mass uptake raise with the $\mathrm{CO}_{2}$ pressure increase but in a non-linear way. Indeed, for every polymer, the $\mathrm{CO}_{2}$ mass uptake is increased by about 40 to $72 \%$ when the $\mathrm{CO}_{2}$ pressure is raised from $5 \mathrm{MPa}$ to $10 \mathrm{MPa}$ whereas only a modest increase of about 4 to $20 \% \mathrm{CO}_{2}$ mass uptake is observed between $10 \mathrm{MPa}$ and $15 \mathrm{MPa}$. This nonlinear relation between the solubility and the pressure increase has been reported for other rubbery polymers [22, 27, 30-32]. Tomasko et al.[33] explained that at high pressure, $\mathrm{CO}_{2}$ sorption is no longer proportional to $\mathrm{CO}_{2}$ pressure. Indeed, at low pressure, $\mathrm{CO}_{2}$ sorption follows Henry's law: $C_{\mathrm{CO}_{2}}=k_{\mathrm{H}} P_{\mathrm{CO}_{2}}$ where $k_{\mathrm{H}}$ is the Henry's coefficient which is dependent of the temperature and the polymer. At high pressure, $k_{H}$ is no longer constant and becomes dependent of the $\mathrm{CO}_{2}$ sorption.

Regarding the corresponding swelling of the polymer that results from the $\mathrm{CO}_{2}$ sorption for a given pressure and temperature, it has been calculated thanks to the polymer peak around $5800 \mathrm{~cm}^{-1}$ and the equation 4. As well as the $\mathrm{CO}_{2}$ mass uptake, the maximum swelling at equilibrium $(\mathrm{S} \%)$ at $50^{\circ} \mathrm{C}$, has been plot for every elastomer and for a $\mathrm{CO}_{2}$ pressure of 5,10 and $15 \mathrm{MPa}$ (see Figure 8) 


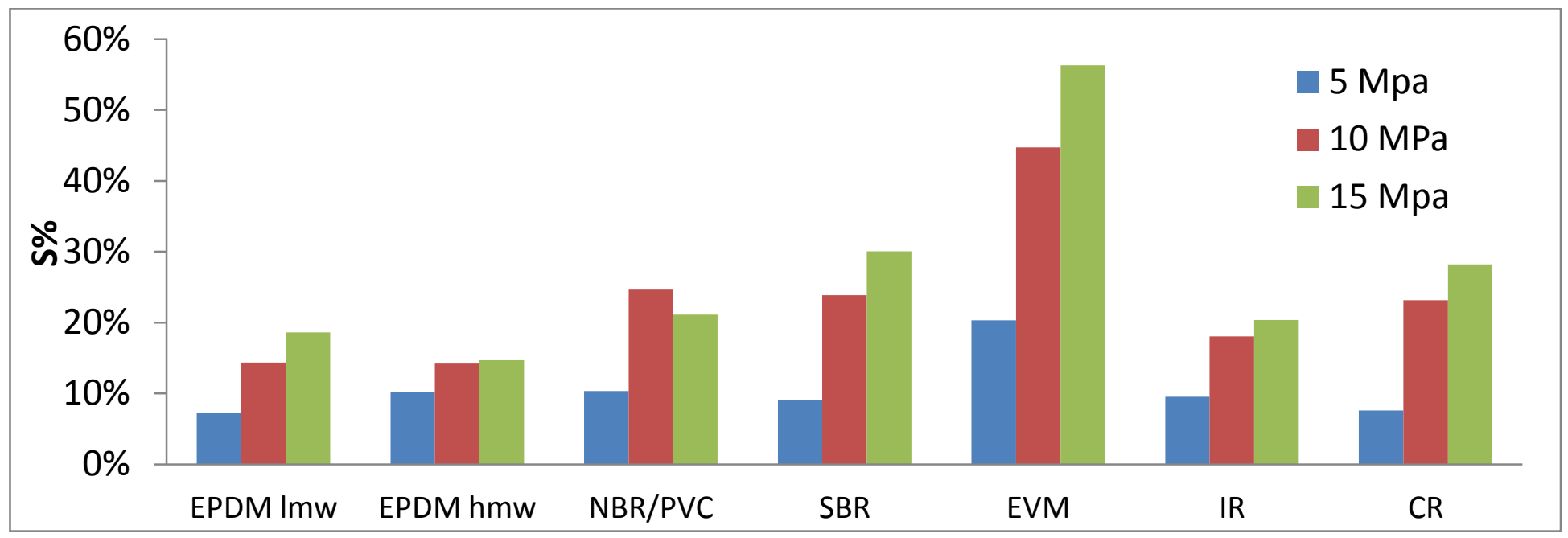

Figure 8 : Polymer swelling as function of pressure, at $\mathrm{T}=50^{\circ} \mathrm{C}$

Therefore, it seems that the swelling value is directly related to the $\mathrm{CO}_{2}$ mass uptake of the studied polymers. In order to quantify the correlation between the swelling of a given polymer and its $\mathrm{CO}_{2}$ mass uptake, we have reported on Figure 9 the swelling as function of $\mathrm{CO}_{2}$ mass uptake for every elastomer. Concerning most ef elastomers, the data are around the dashed line which means that the swelling is directly proportional to the $\mathrm{CO}_{2}$ mass uptake. In contrast, $\mathrm{CR}, \mathrm{SBR}$ and EVM exhibit a higher swelling value compare to $\mathrm{CO}_{2}$ mass uptake. Although the swelling is a complex phenomenon which involve not only the effect of chemical affinity of the polymer with carbon dioxide but also polymer chain mobility and free volume, such behavior can be qualitatively explained by a probable higher chain mobility of CR, SBR and EVM compared to the other polymers investigated in this study. This is particularly true for EVM that contains vinyl acetate groups and is known to display low polymer-polymer interaction thus favouring its swelling and solubility in $\mathrm{scCO}_{2}$ [34]. 


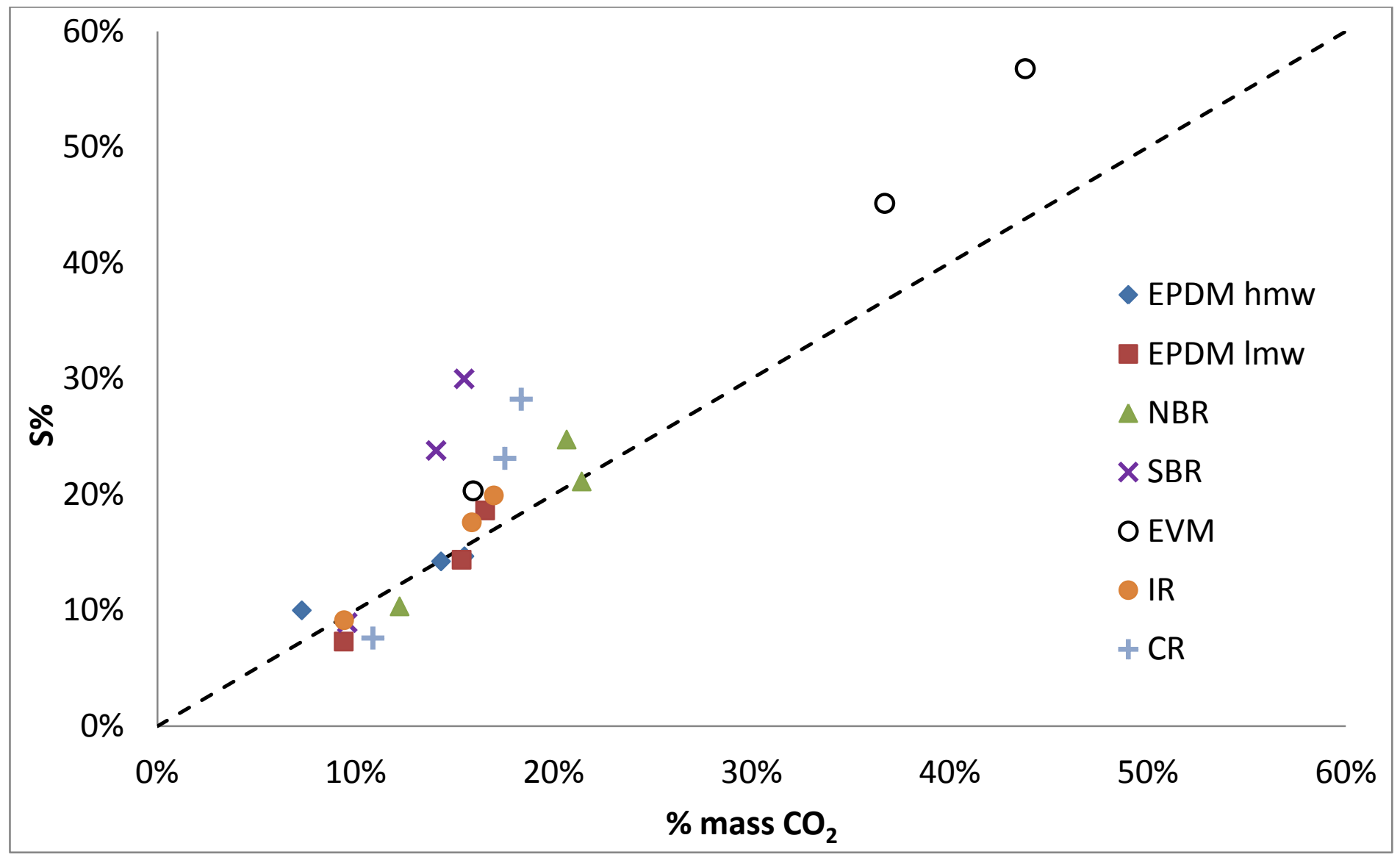

Figure 9 : Polymer swelling $(\mathrm{S} \%)$ as function of $\mathrm{CO}_{2}$ mass uptake $\left(\%\right.$ mass $\left.\mathrm{CO}_{2}\right)$, at $\mathrm{T}=50^{\circ} \mathrm{C}$

\subsection{Effect of temperature on absorption and swelling}

For EPDM 1 , we have performed additional experiments at different temperatures $65^{\circ} \mathrm{C}, 80^{\circ} \mathrm{C}, 95^{\circ} \mathrm{C}$ and $110^{\circ} \mathrm{C}$ in order to evaluate the temperature influence in $\mathrm{CO}_{2}$ mass uptake and swelling. On Figure 10, the maximum $\mathrm{CO}_{2}$ mass uptake at equilibrium is plotted at each temperature and for a $\mathrm{CO}_{2}$ pressure of 5MPa, $10 \mathrm{MPa}$ and $15 \mathrm{MPa}$. Thus, it shows that temperature has only a low effect on mass uptake: from 50 to $110^{\circ} \mathrm{C}$, the mass uptake only decreases from 18 to $16.5 \%$ at $15 \mathrm{MPa}$. Such a low effect of the temperature on $\mathrm{CO}_{2}$ mass uptake has already been reported for HTPB [11], a polymer of similar physico-chemical properties as our elastomer. Indeed, at $15 \mathrm{MPa}$, it shows a modest reduction of mass uptake from about $14 \%$ to $11.5 \%$ for a temperature increase from $40^{\circ} \mathrm{C}$ to $100^{\circ} \mathrm{C}$, which is comparable to our polymers. 


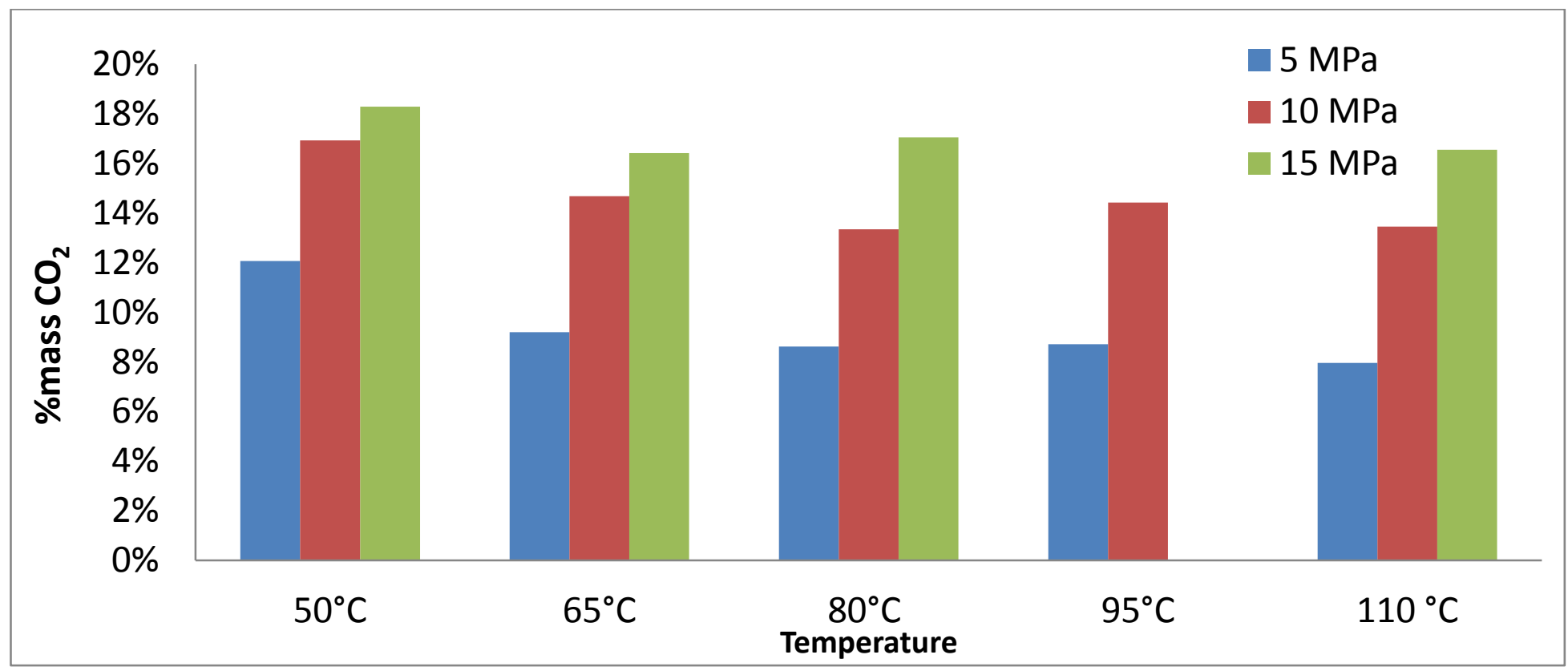

Figure 10 : $\mathrm{CO}_{2}$ mass uptake (\% mass $\mathrm{CO}_{2}$ ) in EPDM1 as function of $\mathrm{CO}_{2}$ pressure and temperature

The swelling of EPDM has also been calculated at $\mathrm{T}=50,65,80,95$ and $110^{\circ} \mathrm{C}$ and for 3 different pressures (see Figure 11). The effect of temperature on the swelling is similar to that reported above for the $\mathrm{CO}_{2}$ mass uptake as it displays only a modest reduction of the swelling upon increase of temperature.

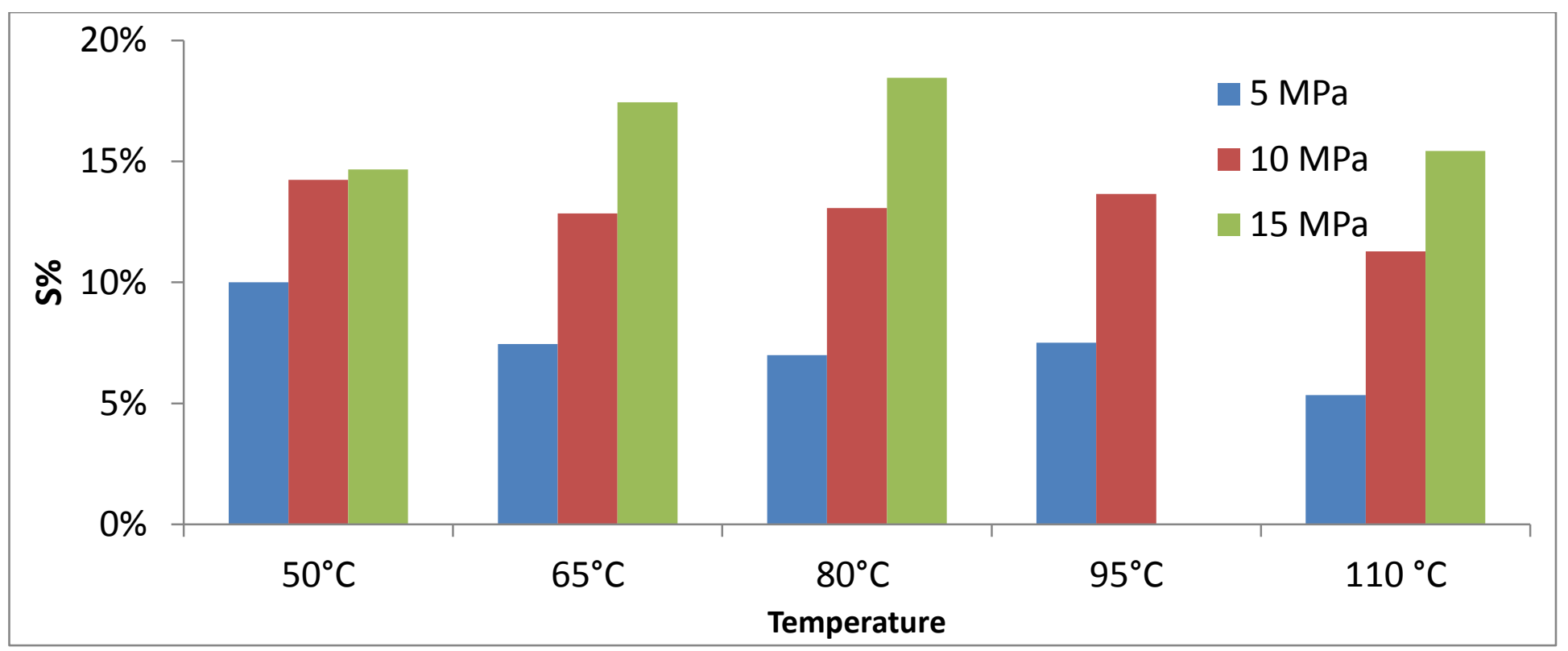

Figure 11 : Swelling of EPDM 1 as function of $\mathrm{CO}_{2}$ pressure and temperature. 


\section{CONCLUSION}

In order to determine in-situ and simultaneously the $\mathrm{CO}_{2}$ sorption and swelling of elastomers by supercritical $\mathrm{CO}_{2}$, we have used an FTIR microscope combined with a high pressure cell. The isothermal behaviour $\left(\mathrm{T}=50^{\circ} \mathrm{C}\right.$ ) as a function of pressure (from 5 to $15 \mathrm{MPa}$ ) of several common elastomers (EPDM, CR, IR, SBR, EVM and NBR) was investigated in order to understand the key parameters governing $\mathrm{CO}_{2}$ sorption and elastomer swelling. The effect of temperature (from 50 to $110^{\circ} \mathrm{C}$ ) as a function of pressure (from 5 to $15 \mathrm{MPa}$ ) has been studied for EPDM. The quantity of $\mathrm{CO}_{2}$ sorbed in all the studied elastomers increases with pressure. All the elastomers display a similar significant level of $\mathrm{CO}_{2}$ sorption between 15 and $20 \%$ wt at $\mathrm{T}=50^{\circ} \mathrm{C}$ and $\mathrm{P}=15 \mathrm{MPa}$. However, we observe that a quite higher quantity of $\mathrm{CO}_{2}$ can be sorbed in EVM in the same conditions (30\%wt). This behaviour was explained by the well-known good affinity between $\mathrm{CO}_{2}$ and the acetate function present in EVM.

The resulting swelling behaviour of most elastomers displays almost the same percentages as than the $\mathrm{CO}_{2}$ mass uptake. In contrast, $C R, S B R$ and EVM exhibit higher swelling values compared to the $\mathrm{CO}_{2}$ mass uptakes. The swelling behavior of most elastomers follows the same trend as the mass uptakes and reaches the same quantitative levels (there is a quasi linear relationship between CO2 uptake \% and swelling \%). In contrast for elastomers having more interactions with $\mathrm{CO}_{2}$ (i.e elastomers containing chlorine or carbonyl groups, CR, EVM), swelling ratios are higher mass uptakes. Besides such behavior can be qualitatively explained by a probable higher chain mobility of CR, SBR and EVM compared to the other elastomers investigated in this study.

Finally, the swelling and $\mathrm{CO}_{2}$ sorption of EPDM displays only a weak variation upon a temperature increase from $50^{\circ} \mathrm{C}$ to $110^{\circ} \mathrm{C}$.

\section{ACKNOWLEGMENTS}

We thank the "Conseil Régional d'Aquitaine" for financial support to the infrared microscopy equipment. 


\section{References}

[1] E. Kiran, Supercritical fluids and polymers - The year in review - 2014, J. Supercrit. Fluids. 110 (2016) 126-153.

[2] N.T. Rao, a. N. Oumer, U.K. Jamaludin, State-of-the-art on flow and heat transfer characteristics of supercritical CO2 in various channels, J. Supercrit. Fluids. 116 (2016) $132-$ 147.

[3] G. Brunner, Applications of Supercritical Fluids, Annu. Rev. Chem. Biomol. Eng. 1 (2010) 321-342.

[4] P. Pollet, E.A. Davey, E.E. Ureña-Benavides, C.A. Eckert, C.L. Liotta, Solvents for sustainable chemical processes, Green Chem. 16 (2014) 1034-1055.

\section{J. Wang, W. Zhu, H. Zhang, C.B. Park, Continuous processing of low-density, microcellular poly(lactic acid) foams with controlled cell morphology and crystallinity, Chem. Eng. Sci. 75 (2012) 390-399.}

[6] F. Belhadj-Ahmed, E. Badens, P. Llewellyn, R. Denoyel, G. Charbit, Impregnation of vitamin E acetate on silica mesoporous phases using supercritical carbon dioxide, J. Supercrit. Fluids. 51 (2009) 278-286..

[7] A. Şen, M.M.R. De Melo, A.J.D. Silvestre, H. Pereira, C.M. Silva, Prospective pathway for a green and enhanced friedelin production through supercritical fluid extraction of Quercus cerris cork, J. Supercrit. Fluids. 97 (2015) 247-255.

[8] A. Jonquières, R. Clèment, P. Lochon, Permeability of block copolymers to vapors and liquids, Prog. Polym. Sci. 27 (2002) 1803-1877.

[9] Y. Yuan, A.S. Teja, Quantification of specific interactions between CO2 and the carbonyl group in polymers via ATR-FTIR measurements, J. Supercrit. Fluids. 56 (2011) 208-212.

[10] A. a. Gabrienko, A. V. Ewing, A.M. Chibiryaev, A.M. Agafontsev, K. a. Dubkov, S.G. Kazarian, New insights into the mechanism of interaction between $\mathrm{CO}_{2}$ and polymers from thermodynamic parameters obtained by in situ ATR-FTIR spectroscopy, Phys. Chem. Chem. Phys. 18 (2016) 6465-6475.

[11] P. Vitoux, T. Tassaing, F. Cansell, S. Marre, C. Aymonier, In Situ IR Spectroscopy and Ab Initio Calculations To Study Polymer Swelling by Supercritical CO 2, J. Phys. Chem. B. (2009) 897-905.

[12] J. Pinto, M. Dumon, M. Pedros, J. Reglero, M.A. Rodriguez-Perez, Nanocellular CO2 foaming of PMMA assisted by block copolymer nanostructuration, Chem. Eng. J. 243 (2014) 428-435.

[13] Y. Sato, K. Fujiwara, T. Takikawa, Sumarno, S. Takishima, H. Masuoka, Solubilities and diffusion coefficients of carbon dioxide and nitrogen in polypropylene, high-density polyethylene, and polystyrene under high pressures and temperatures., Fluid Phase Equilib. vol. 162 (1999) 261-276. 
[14] D. Hu, J. Chen, S. Sun, T. Liu, L. Zhao, Solubility and Di ff usivity of CO 2 in Isotactic Polypropylene / Nanomontmorillonite Composites in Melt and Solid States, 53 (2014) 2673-2683.

[15] T. Takajo, A. Takahara, T. Kichikawa, Surface Modification of Engineering Plastics through Swelling in Supercritical Carbon Dioxide, Polym. J. 40 (2008) 716-724.

[16] K.J. Thurecht, D.J.T. Hill, A.K. Whittaker, Equilibrium swelling measurements of network and semicrystalline polymers in supercritical carbon dioxide using high-pressure NMR, Macromolecules. 38 (2005) 3731-3737.

[17] H.D. Huang, P.G. Ren, J.Z. Xu, L. Xu, G.J. Zhong, B.S. Hsiao, Z.M. Li, Improved barrier properties of poly(lactic acid) with randomly dispersed graphene oxide nanosheets, J. Memb. Sci. 464 (2014) 110-118.

18 J. Pinto, J. Reglero, M. Dumon, M.A. Rodriguez-Perez, Temperature influence and $\mathrm{CO}_{2}$ transport in foaming processes of polymethylmethacrylate - block copolymer nano cellular or micr cellular foams, J. Supercrit. Fluids. 94 (2014) 198-205.

[19] S.K. Goel, E.J. Beckman, Modelling the swelling of crosslinked elastomers by supercritical fluids, Polymer (Guildf). 33 (1992) 5032-5039.

[20] F. Daou, C.R. de Miranda, J.L. de Oliveira, B. Engelke, C. Borman, S. Le Roy-Delage, B. Lungwitz, Swelling of Elastomers in CO2 Environment: Testing Methodology and Experimental Data, in: Soc. Pet. Eng. Lat. Am. Caribb. Pet. Eng. Conf. Proc., 2014: p. SPE169277-MS.

[21] L.M. Robeson, Q. Liu, B.D. Freeman, D.R. Paul, Comparison of transport properties of rubbery and glassy polymers and the relevance to the upper bound relationship, J. Memb. Sci. 476 (2015) 421-431.

[22] S. Shenoy, D. Woerdeman, R. Sebra, A. Garach-Domech, K.J. Wynne, Quantifying polymer swelling employing a linear variable differential transformer: CO2 effects on SBS triblock copolymer, Macromol. Rapid Commun. 23 (2002) 1130-1133.

[23] M. Champeau, J.M. Thomassin, C. Jérôme, T. Tassaing, In situ FTIR micro-spectroscopy to investigate polymeric fibers under supercritical carbon dioxide: $\mathrm{CO} 2$ sorption and swelling measurements, J. Supercrit. Fluids. 90 (2014) 44-52.

[24] T. Guadagno, S.G. Kazarian, High-pressure CO2-expanded solvents: Simultaneous measurement of $\mathrm{CO} 2$ sorption and swelling of liquid polymers with in-situ near-IR spectroscopy, J. Phys. Chem. B. 108 (2004) 13995-13999.

[25] S. Foltran, E. Cloutet, H. Cramail, T. Tassaing, In situ FTIR investigation of the solubility and swelling of model epoxides in supercritical CO 2, J. Supercrit. Fluids. 63 (2012) 52-58.

[26] NIST: webbook.nist.gov/chemistry/

[27] W. Michaeli, K. Westermann, S. Sitz, Extrusion of physically foamed rubber profiles, Cell. Plast. 47 (2011) 483-495.

[28] M.A. Jacobs, M.F. Kemmere, J.T.F. Keurentjes, Foam processing of poly(ethylene-co-vinyl acetate) rubber using supercritical carbon dioxide, Polymer (Guildf). 45 (2004) 7539-7547. 
[29] E. Girard, T. Tassaing, J.D. Marty, M. Destarac, Structure-Property Relationships in CO2-philic (Co)polymers: Phase Behavior, Self-Assembly, and Stabilization of Water/CO2 Emulsions, Chem. Rev. 116 (2016) 4125-4169.

[30] S.H. Chang, S.C. Park, J.J. Shim, Phase equilibria of supercritical fluid-polymer systems, J. Supercrit. Fluids. 13 (1998) 113-119.

[31] N.M.B. Flichy, S.G. Kazarian, C.J. Lawrence, B.J. Briscoe, An ATR-IR study of poly (dimethylsiloxane) under high-pressure carbon dioxide: Simultaneous measurement of sorption and swelling, J. Phys. Chem. B. 106 (2002) 754-759.

[32] Y.T. Shieh, Y.G. Lin, Equilibrium solubility of CO2 in rubbery EVA over a wide pressure range: Effects of carbonyl group content and crystallinity, Polymer (Guildf). 43 (2002) 18491856.

[33] D.L. Tomasko, H.B. Li, D.H. Liu, X.M. Han, M.J. Wingert, L.J. Lee, K.W. Koelling, A review of $\mathrm{CO}(2)$ applications in the processing of polymers, Ind. Eng. Chem. Res. 42 (2003) 64316456.

[34] X. Liu, O. Coutelier, S. Harrisson, T. Tassaing, J.-D. Marty, M. Destarac, Enhanced Solubility of Polyvinyl Esters in $\mathrm{scCO}_{2}$ by Means of Vinyl Trifluorobutyrate Monomer, ACS Macro Lett. 4 (2015) 89-93.

\section{Figure captions}

Figure 1 Experimental setup

Figure 2 Evolution of the absorbance of the peak centered at $4950 \mathrm{~cm}-1$ (normalized unit) at $\mathrm{T}=50^{\circ} \mathrm{C}$ and $\mathrm{P}=5 \mathrm{MPa}$

Figure 3: Infrared spectra of EPDM at $50^{\circ} \mathrm{C}$ under $\mathrm{CO}_{2}$ pressure of $5 \mathrm{MPa}, 10 \mathrm{MPa}$ and $15 \mathrm{MPa} \ldots . .7$ Figure 4: Infrared spectra of $\mathrm{CO}_{2}$ at $\mathrm{T}=50^{\circ} \mathrm{C}$ and $\mathrm{P}=5 \mathrm{MPa}$ (neat gaseous $\mathrm{CO}_{2}$ ), $\mathrm{P}=10 \mathrm{MPa}$ (neat $\left.\mathrm{scCO}_{2}\right)$ and $\mathrm{P}=10 \mathrm{MPa}\left(\mathrm{CO}_{2}\right.$ in $\left.\mathrm{EPDM}\right)$

Figure $6: \mathrm{CO}_{2}$ concentration (neat $\mathrm{CO}_{2}$ ) as function of absorbance of $4950 \mathrm{~cm}^{-1}$ peaks for path length calculation, at $\mathrm{T}=50^{\circ} \mathrm{C}$

Figure $7: \%$ mass $\mathrm{CO}_{2}$ in EPDM data points at 50,100 and 150 bars and $50^{\circ} \mathrm{C}$, calculated thanks to every $\mathrm{CO}_{2}$ specific peaks.

Figure $8: \mathrm{CO}_{2}$ mass uptake $\left(\%\right.$ mass $\left.\mathrm{CO}_{2}\right)$ as function of pressure, in every studied elastomer, at $\mathrm{T}=$ $50^{\circ} \mathrm{C}, \mathrm{P}=5 \mathrm{MPa}, \mathrm{P}=10 \mathrm{MPa}$ and $\mathrm{P}=15 \mathrm{MPa}$

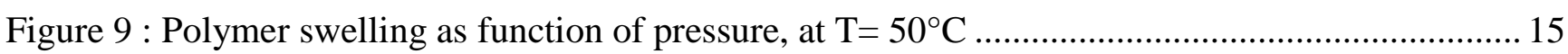

Figure 10 : Polymer swelling $(\mathrm{S} \%)$ as function of $\mathrm{CO}_{2}$ mass uptake $\left(\%\right.$ mass $\left.\mathrm{CO}_{2}\right)$, at $\mathrm{T}=50^{\circ} \mathrm{C} \ldots \ldots \ldots . .16$

Figure $11: \mathrm{CO}_{2}$ mass uptake (\%mass $\mathrm{CO}_{2}$ ) in $\mathrm{EPDM}$ as function of $\mathrm{CO}_{2}$ pressure and temperature ... 17

Figure 12 : Swelling of EPDM as function of $\mathrm{CO}_{2}$ pressure and temperature. 